\title{
Are Conspiracy Theories Harmless?
}

\author{
Karen M. Douglas \\ University of Kent (UK)
}

\begin{abstract}
In recent years, there has been an increasing interest in the consequences of conspiracy theories and the COVID19 pandemic raised this interest to another level. In this article, I will outline what we know about the consequences of conspiracy theories for individuals, groups, and society, arguing that they are certainly not harmless. In particular, research suggests that conspiracy theories are associated with political apathy, support for non-normative political action, climate denial, vaccine refusal, prejudice, crime, violence, disengagement in the workplace, and reluctance to adhere to COVID-19 recommendations. In this article, I will also discuss the challenges of dealing with the negative consequences of conspiracy theories, which present some opportunities for future research.
\end{abstract}

Received 28 October 2020; Revised 18 January 2021; Accepted 20 January 2021

Keywords: conspiracy theories, health, politics, prejudice, COVID-19

In March 2020, the world was faced with the reality of a global pandemic, and almost as soon as the news started to emerge about COVID-19, so did the conspiracy theories. Was the virus a hoax to control the general public? Was it a Chinese bioweapon designed to wage war on the U.S.? Did 5G phone masts spread the virus? To those of us who study the psychology of conspiracy theories, the emergence of new conspiracy theories at this time did not come as a huge surprise. Indeed, conspiracy theories have always tended to surface in times of crisis and unrest (van Prooijen \& Douglas, 2017). However, conspiracy theories like these are not harmless-instead, they bring with them significant and damaging consequences. In this article, I will summarize what we know so far about the consequences of conspiracy theories, and will also outline some challenges for dealing with them.

\section{Why People Believe in Conspiracy Theories}

Conspiracy theories explain significant events and circumstances as the secret and malicious acts of powerful groups (Douglas et al., 2019). Research on the psychology of conspiracy theories has grown significantly in the past 15 years, focusing predominantly on why some people are inclined toward conspiracy theories while

Correspondence concerning this article should be addressed to Karen M. Douglas. University of Kent. School of Psychology. CT2 7NP Canterbury (UK).

E-mail: k.douglas@kent.ac.uk

Conflicts of Interest: None.

Funding Statement: This research received no specific grant from any funding agency, commercial or not-for-profit sectors. others are not. This literature suggests that people are drawn to conspiracy theories in an attempt to satisfy important psychological needs (Douglas et al., 2017).

The first of these-epistemic-relate to the needs for knowledge and clarity. For example, when people feel uncertain they are more drawn to conspiracy theories (van Prooijen \& Jostman, 2013), and conspiracy theories seem to appeal more to people who show a tendency to look for patterns and meaning in chaos (van Prooijen et al., 2018). The second set of needs-existential-refer to the needs people have to feel safe, secure, and in control. For example, people tend to believe conspiracy theories more when they are anxious (GrzesiakFeldman, 2013) and when they feel powerless (Abalakina-Paap et al., 1999). Finally people have social needs to feel good about themselves and the groups to which they belong, and these needs also seem to lead people toward conspiracy theories. For example, people who want to feel unique compared to others are more likely to believe in conspiracy theories (Lantian et al., 2017), as are people who feel that a social group to which they belong is important but underappreciated by others (Cichocka et al., 2016).

\section{Consequences of Conspiracy Theories}

While there is growing consensus among researchers regarding the psychological underpinnings of

How to cite this article:

Douglas, K. M. (2021). Are conspiracy theories harmless? The Spanish Journal of Psychology, 24. e13. Doi:10.1017/SJP.2021.10 
conspiracy beliefs, the consequences of conspiracy theories are less well understood. Some theorists argue that there may be positive outcomes. Specifically, conspiracy theories may provide a sense of community for people with marginal views (Franks et al., 2017). They may also open up opportunities for political debate (Miller, 2002), increase accountability (Basham, 2003; Dentith, 2016), encourage greater transparency (Swami \& Coles, 2010) and inspire people to mobilize toward collective goals with the intention to bring about social change (Imhoff \& Bruder, 2014; Mari et al., 2017). Some scholars view conspiracy theories as a result of people's attempts to understand social and political reality (Knight, 2001; Radnitz \& Underwood, 2017), and therefore as an important ingredient of democratic discourse (Moore, 2016).

However, so far the positive outcomes of conspiracy theorizing seem to be heavily outweighed by the negative psychological and societal consequences which have been studied more comprehensively in psychology and other social sciences. In the following sections, I will outline what we know so far about these consequences.

\section{Attitudes and Attitude Change}

In one of the first investigations of the consequences of conspiracy theories, Butler et al. (1995) found that they are persuasive. Butler et al. asked participants who had just viewed the Oliver Stone film JFK-which presented a conspiracy narrative about the assassination of President John F. Kennedy-to rate their agreement with the conspiracy story. Compared to participants who had not yet viewed the film, those exiting the cinema agreed significantly more with the conspiracy story. Douglas and Sutton (2008) found similar results with respect to conspiracy theories about the death of Princess Diana. Specifically, people who read conspiracy theories about her death agreed more that the event was due to a conspiracy. Douglas and Sutton further demonstrated that people were not aware that their attitudes had changed as a result of reading the conspiracy theories.

These attitude change effects may depend on people's pre-existing attitudes. For example, Uscinski et al. (2016) included the word "conspiracy" in a survey about media coverage during the 2012 U.S. presidential election. Half of the surveys included this word and the other half did not. Uscinski and colleagues found that the inclusion of the word "conspiracy" only influenced people who had also scored high in a general tendency toward conspiracy thinking. Overall, these findings suggest that conspiracy theories can have a significant impact on people's attitudes, and even more so if people are already inclined to believe in conspiracy theories. In online environments where "echo chambers" of conspiracy believers are almost exclusively exposed to conspiracy content, attitudes can become more polarized and extreme (del Vicario et al., 2016; Bessi et al., 2015).

\section{Politics, Extremism, Crime, and Violence}

A number of studies suggest that conspiracy theories have consequences for people's political intentions. Jolley and Douglas (2014a) found that people who were asked to read anti-government conspiracy theories were less inclined to vote in the next election, compared to participants who had been given information refuting those conspiracy theories. Butler et al (1995) also showed that people were less likely to want to engage in politics after watching the film JFK. After reading conspiracy theories, people also tend to indicate that their trust in politics has diminished (Einstein \& Glick, 2015). Furthermore, people who show a general tendency toward conspiracy theories are less inclined to register to vote, donate to a political campaign, or display political signs outside their homes (Uscinski \& Parent, 2014).

Aside from this political apathy however, conspiracy theories may sometimes be associated with radicalized and extremist activities. Indeed, they have been linked to non-normative political actions such as protests (Imhoff \& Bruder, 2014) and illegal actions such as occupying buildings (Mari et al., 2017). Bartlett and Miller (2010) found that conspiracy theorizing was prevalent in online extremist groups, both for extreme right- and extreme left-wing groups. Conspiracy theories may therefore be a "radicalizing multiplier" (p. 4) that serves to reinforce ideologies and psychological processes within extremist groups. Recently, Rottweiler and Gill (2020) found a link between conspiracy beliefs and violent extremist intentions. Specifically, these relationships were stronger for individuals who have low self-control, have weaker morality when it comes to the law, but score higher in self-efficacy.

More generally, conspiracy beliefs have been associated with intentions to engage in violence. Uscinski and Parent (2014) found that people who were more predisposed to conspiracy theories were more likely than others to agree that "violence is sometimes an acceptable way to express disagreement with the government". People inclined toward conspiracy theories also show a greater willingness to conspire themselves (Douglas \& Sutton, 2011), more relaxed attitudes towards gun ownership (Uscinski \& Parent, 2014) and are more likely to engage in everyday small crimes such as running red traffic lights and paying for goods with cash to avoid taxation (Jolley et al., 2019). 


\section{Prejudice, Discrimination, and Intergroup Relations}

Conspiracy theories are also associated with negative attitudes towards outgroups. In one study, Swami (2012) asked Malaysian participants to indicate their belief in conspiracy theories generally, their belief in anti-Jewish conspiracy theories (e.g., that Jews are trying to establish a secret world government), and attitudes towards Israelis amongst other ideological attitudes. Belief in anti-Jewish conspiracy theories was associated with anti-Israeli attitudes but also racism towards Chinese people. In experimental studies, Jolley et al. (2020) found that exposure to anti-Jewish conspiracy theories predicted prejudice and discrimination toward Jews, but also prejudice toward groups who were not part of the alleged conspiracy, such as Americans, Asians, and Arabs. Overall, this research suggests that conspiracy theories may have damaging and broad implications for intergroup relations.

Other research has linked anti-Jewish conspiracy beliefs to anti-Semitic attitudes generally (Golec de Zavala \& Cichocka, 2012) and discrimination toward Jews (Bilewicz et al., 2013). These beliefs appear to be largely driven by feelings of political uncontrollability (Kofta et al., 2020). Imhoff and Bruder (2014) also showed that a tendency toward conspiracy theorizing was associated with prejudice towards high-power groups such as Jews and Americans. Conspiracy theories may therefore reinforce an "us" versus "them" dichotomy, further reinforcing tensions between groups.

\section{Climate Attitudes and Science Denialism}

Climate denial is prominent in the U.S. (Uscinski et al., 2017) and is linked to conspiracy beliefs such as the idea that climate change is a hoax fabricated by climate scientists to win research funding (Douglas \& Sutton, 2015). Jolley and Douglas (2014b) showed that these conspiracy theories negatively influence people's intentions to become more energy efficient and reduce their carbon footprint. Specifically, people who read about climate change conspiracy theories felt powerless, uncertain, and disillusioned, and were in turn less inclined to take climate action. Another study has shown that climate change conspiracy theories also reduce intentions to sign a petition to help reduce the impact of global warming (van der Linden, 2015).

A significant number of studies have shown that conspiracy theories about climate change go hand in hand with science denial more generally (e.g., Lewandowsky et al., 2015; Lewandowsky et al., 2013; Uscinski et al., 2017). Many other conspiracy theories express mistrust in science and rejection of scientific findings. For example, conspiracy beliefs have been linked to negative attitudes about genetically modified food, vaccination, the origins of the AIDS virus, forensic evidence about the 9/11 attacks, and beliefs about the origins of COVID-19 (see also Rutjens et al., 2018).

\section{Health Choices}

Several studies have also linked belief in conspiracy theories to risky healthy choices. For example, conspiracy beliefs alleging that birth control is a form of genocide against Africans and African Americans are associated with more negative attitudes towards contraception in the U.S. (e.g., Thorburn Bird \& Bogart, 2003; Thorburn \& Bogart, 2005). Perceived discrimination against African Americans also plays a role in the rejection of contraception (e.g., Bogart \& Thorburn Bird, 2003), and similar findings have been found in South Africa where these conspiracy theories are also popular (Grebe \& Natrass, 2012).

Oliver and Wood (2014) found in U.S. nationally representative samples that over half of the population believes in one health-related conspiracy theory (e.g., that mobile phones cause cancer but this fact is hidden by health officials). They further found that believers were less likely to trust medical professionals and were more likely to look elsewhere (e.g., alternative medicines) for treatment (see also Lamberty \& Imhoff, 2018). Experimental research has shown that anti-vaccine conspiracy beliefs significantly decrease people's intentions to vaccinate (Jolley \& Douglas, 2014b), and qualitative research exploring people's vaccination decisions has found that conspiracy theories play a significant role in these decisions (Craciun \& Baban, 2012; Khan \& Sahibzada, 2016).

\section{Work Choices}

Furthermore, a small number of studies have examined the consequences of conspiracy beliefs in the workplace. van Prooijen and de Vries (2016) found that believing conspiracies happen in the workplace was associated with increased turnover intentions due to reduced organizational commitment. In experimental studies, Douglas and Leite (2017) found that participants who were asked to imagine a conspiratorial workplace were more likely to want to leave the workplace compared to participants in a control condition. This effect was driven by lower feelings of commitment to the workplace, and lower job satisfaction. Others have argued that rumors and gossip may be detrimental to the workplace (DiFonzo et al., 1994), and research suggests that conspiracy theories at work may also be more than just trivial ideas shared during break times.

\section{COVID-19 Conspiracy Theories}

Finally, recent research has examined some of the consequences of believing in conspiracy theories about 
COVID-19. In particular, this research has shown that belief in these conspiracy theories has negative consequences for people's intentions to comply with government recommendations to reduce the spread of the virus. For example, Romer and Jamieson (2020) found that belief in COVID-19 conspiracy theories in the U.S. was associated with lower perceived threat of the pandemic, less likelihood of taking preventive action (e.g., wearing a mask), and refusal of a vaccine if one became available. Imhoff and Lamberty (2020) found that "hoax" conspiracy theories in particular predicted refusal of preventive behaviors, but conspiracy beliefs that the virus is a bioweapon were associated with more self-centered prepping behavior. Furthermore, Biddlestone et al. (2020) demonstrated that people with an individualist (versus collectivist) mindset were less likely to engage in COVID-19 preventive behaviors, a relationship mediated by belief in COVID-19 conspiracy theories.

Other negative consequences of COVID-19 conspiracy theories include willingness to engage in vandalism of $5 \mathrm{G}$ phone masts and violence more generally (Jolley \& Paterson, 2020), and a large number of unpublished preprints available on psycharxiv.com suggest that belief in COVID-19 conspiracy theories is also associated with outcomes such as support for alternative remedies, and stockpiling. Like many other types of conspiracy theories, COVID-19 conspiracy theories therefore also appear to do harm.

\section{Dealing with Conspiracy Theories: Practical Solutions and Future Research}

Research suggests that it is difficult to address the consequences of conspiracy theories because such theories are so nebulous and are often unfalsifiable, making them difficult to tackle head on (e.g., Lewandowsky et al., 2012). People who believe in conspiracy theories are also typically very committed to their beliefs, which are often driven by political attitudes and beliefs associated with important group memberships (Uscinski et al., 2016). Such ties are hard to break. However, as we have seen in the case of COVID-19 conspiracy theories, promoting a collectivist mindset may help people resist the temptation of conspiracy theories (Biddlestone et al., 2020). Promoting a more collectivist mindset may therefore also be a way in general to break the negative consequences that "us" versus "them" conspiracy theorizing can bring.

Another challenge in dealing with conspiracy theories is that when trusted and influential sources of information argue in favor of conspiracy theories, potentially damaging ideas can gain traction. People may be reluctant to accept counterarguments from governments or other official sources who are typically viewed as "outgroups". However, one option for dealing with conspiracy theories might be to use trusted influential messengers to present counterarguments. In other words, combating conspiracy theories is likely to be more successful if the counterarguments come from people who are trusted, such as valued ingroup members (Nisbet, 2009).

Another possibility for dealing with conspiracy theories uses a similar idea to the principle of inoculation in vaccinations. Specifically, "inoculating" people with factual information can curtail the impact of conspiracy theories. For example, Jolley and Douglas (2017) showed that for anti-vaccine conspiracy theories, pro-vaccine counterarguments were effective in improving intentions to vaccinate if presented prior to the conspiracy theories. However, once the conspiracy theories had already been presented, they were difficult to counter with provaccine arguments. A related strategy may be to present people with pre-exposure warnings to let people know that there is a possibility that future information is intended to mislead them (Lewandowsky et al., 2012). Serious games using similar techniques have already been shown to effectively reduce the impact of misinformation more generally (Maertens et al., 2020).

Finally, earlier in this article I wrote about the psychological needs that draw people toward conspiracy theories (Douglas et al., 2017). A broader and longerterm strategy for dealing with conspiracy theories might be to attempt to address these psychological needs directly. To do so, a more nuanced understanding of how these needs fluctuate over time and with changing political and social circumstances may be needed. However, focusing on people's psychological needs and attempting to address those needs by means other than conspiracy theories might make conspiracy theories less appealing. It might also improve people's day to day wellbeing.

\section{Conclusions}

Conspiracy theories are associated with a range of negative consequences for political engagement, political behavior, climate engagement, trust in science, vaccine uptake, civic behavior, work-related behavior, intergroup relations, and more recently the COVID-19 response. A significant challenge for researchers is to learn how to deal with conspiracy theories and their associated effects.

\section{References}

Abalakina-Paap, M., Stephan, W. G., Craig, T., \& Gregory, L. W. (1999). Beliefs in conspiracies. Political Psychology, 20(3), 637-647. https: / / doi.org/10.1111/0162-895X.00160 
Bartlett, J., \& Miller, C. (2010). The power of unreason: Conspiracy theories, extremism and counter-terrorism. Demos.

Basham, L. (2003). Malevolent global conspiracy. Journal of Social Philosophy, 34(1), 91-103. https:/ / doi.org/10.1111/ 1467-9833.00167

Bessi, A., Coletto, M., Davidescu, G. A., Scala, A., Caldarelli, G., \& Quattrociocchi, W. (2015). Science vs conspiracy: Collective narratives in the age of misinformation. PLOS ONE, 10(2), Article e0118093. https://doi.org/10.1371/ journal.pone. 0118093

Biddlestone, M., Green, R., \& Douglas, K. M. (2020). Cultural orientation, power, belief in conspiracy theories, and intentions to reduce the spread of COVID-19. British Journal of Social Psychology, 59(3), 663-673. https: / / doi.org/10.1111/ bjso. 12397

Bilewicz, M., Winiewski, M., Kofta, M., \& Wójcik, A. (2013). Harmful ideas: The structure and consequences of anti-Semitic beliefs in Poland. Political Psychology, 34(6), 821-839. http://doi.org/10.1111/pops.12024

Bogart, L. M., \& Thorburn Bird, S. (2003). Exploring the relationship of conspiracy beliefs about HIV / AIDS to sexual behaviors and attitudes among African-American adults. Journal of the National Medical Association, 95(11), 1057-1065.

Butler, L. D., Koopman, C., \& Zimbardo, P. G. (1995). The psychological impact of viewing the film "JFK": Emotions, beliefs, and political behavioral intentions. Political Psychology, 16(2), 237-257. https: / / www.jstor.org/stable/ 3791831

Cichocka, A., Marchlewska, M., \& Golec de Zavala, A. (2016). Does self-love or self-hate predict conspiracy beliefs? Narcissism, self-esteem and the endorsement of conspiracy theories. Social Psychological and Personality Science, 7(2), 157-166. https:/ / doi.org/10.1177/1948550615616170

Craciun, C., \& Baban, A. (2012). "Who will take the blame?" Understanding the reasons why Romanian mothers decline HPV vaccination for their daughters. Vaccine, 30(48), 6789-6793. https:/ / doi.org/10.1016/j.vaccine.2012.09.016

Del Vicario, M., Vivaldo, G., Bessi, A., Zollo, F., Scala, A., Caldarelli, G., \& Quattrociocchi, W. (2016). Echo chambers: Emotional contagion and group polarization on Facebook. Scientific Reports, 6, Article 37825. https: / / doi.org/10.1038/ srep37825

Dentith, M. R. X. (2016). When inferring to a conspiracy might be the best explanation. Social Epistemology, 30(5-6), 572-591. https: / / doi.org/10.1080/02691728.2016.1172362

DiFonzo, N., Bordia, P., \& Rosnow, R. L. (1994). Reining in rumors. Organizational Dynamics, 23(1), 47-62. https: / / doi.org/10.1016/0090-2616(94)90087-6

Douglas, K. M., \& Leite, A. C. (2017). Suspicion in the workplace: Organizational conspiracy theories and workrelated outcomes. British Journal of Psychology, 108(3), 486-506. https:/ / doi.org/10.1111/bjop.12212

Douglas, K. M., \& Sutton, R. M. (2008). The hidden impact of conspiracy theories: Perceived and actual influence of theories surrounding the death of Princess Diana. The Journal of Social Psychology, 148(2), 210-222. https: / / doi.org/ 10.3200/SOCP.148.2.210-222
Douglas, K. M., \& Sutton, R. M. (2011). Does it take one to know one? Belief in conspiracy theories is influenced by personal willingness to conspire. British Journal of Social Psychology, 50(3), 544-552. https://doi.org/10.1111/j.20448309.2010.02018.x

Douglas, K. M., \& Sutton, R. M. (2015). Climate change: Why the conspiracy theories are dangerous. Bulletin of the Atomic Scientists, 71(2), 98-106. https:/ / doi.org/10.1177/ 0096340215571908

Douglas, K. M., Sutton, R. M., \& Cichocka, A. (2017). The psychology of conspiracy theories. Current Directions in Psychological Science, 26(6), 538-542. https:/ / doi.org/ $10.1177 / 0963721417718261$

Douglas, K. M., Uscinski, J. E., Sutton, R. M., Cichocka, A., Nefes, T., Ang, C. S., \& Deravi, F. (2019). Understanding conspiracy theories. Political Psychology, 40(S1), 3-35. https:/ / doi.org/10.1111/pops.12568

Einstein, K. L., \& Glick, S. (2015). Do I think BLS data are BS? The consequences of conspiracy theories. Political Behavior, 37, 679-701. https:/ / doi.org/10.1007/s11109-014-9287-z

Franks, B., Bangerter, A., Bauer, M. W., Hall, M., \& Noort, M. C. (2017). Beyond "monologicality"? Exploring conspiracist worldviews. Frontiers in Psychology, 8. https://doi.org/ 10.3389/fpsyg.2017.00861

Golec de Zavala, A., \& Cichocka, A. (2012). Collective narcissism and anti-Semitism in Poland. Group Processes and Intergroup Relations, 15(2), 213-229. https: / / doi.org/ $10.1177 / 1368430211420891$

Grebe, E. G., \& Nattrass, N. (2012). AIDS conspiracy beliefs and unsafe sex in Cape Town. AIDS and Behavior, 16(3), 761-773. http: / / doi.org/10.1007/s10461-011-9958-2

Grzesiak-Feldman, M. (2013). The effect of high-anxiety situations on conspiracy thinking. Current Psychology, 32, 100-118. http: / / doi.org/10.1007/s12144-013-9165-6

Imhoff, R., \& Bruder, M. (2014). Speaking (un-)truth to power: Conspiracy mentality as a generalized political attitude. European Journal of Personality, 28(1), 25-43. https:/ / doi.org/ 10.1002/per.1930

Imhoff, R., \& Lamberty, P. (2020). A bioweapon or a hoax? The link between distinct conspiracy beliefs about the coronavirus disease (COVID-19) outbreak and pandemic behavior. Social Psychological and Personality Science, 11(8). https://doi.org/10.1177/1948550620934692

Jolley, D., \& Douglas, K. M. (2017). Prevention is better than cure: Addressing anti-vaccine conspiracy theories. Journal of Applied Social Psychology, 47(8), 459-469. https: / / doi.org/ 10.1111/jasp.12453

Jolley, D., \& Douglas, K. M. (2014a). The social consequences of conspiracism: Exposure to conspiracy theories decreases intentions to engage in politics and to reduce one's carbon footprint. British Journal of Psychology, 105(1), 35-36. https: / / doi.org/10.1111/bjop.12018

Jolley, D., \& Douglas, K. M. (2014b). The effects of anti-vaccine conspiracy theories on vaccination intentions. PLOS ONE, 9 (2). Article e89177 https:/ / doi.org/10.1371/ journal.pone.0089177

Jolley, D., Douglas, K., Leite, A., \& Schrader, T. (2019). Belief in conspiracy theories and intentions to engage in everyday 
crime. British Journal of Social Psychology, 58(3), 534-549.

https: / / doi.org/10.1111/bjso.12311

Jolley, D., Meleady, R., \& Douglas, K. M. (2020). Exposure to intergroup conspiracy theories promotes prejudice which spreads across groups. British Journal of Psychology, 111(1), 17-35. https: / / doi.org/10.1111/bjop.12385

Jolley, D., \& Paterson, J. L. (2020). Pylons ablaze: Examining the role of 5G COVID-19 conspiracy beliefs and support for violence. British Journal of Social Psychology, 59(3), 628-640. https: / / doi.org/10.1111/bjso.12394

Khan, T. M., \& Sahibzada, M. U. K. (2016). Challenges to health workers and their opinions about parents' refusal of oral polio vaccination in the Khyber Pakhtoon Khawa (KPK) province, Pakistan. Vaccine, 34(18), 2074-2081. https: / / doi.org/10.1016/j.vaccine.2016.03.008

Knight, P. (2001). ILOVEYOU: Viruses, paranoia, and the environment of risk. The Sociological Review, 48(S2), 17-30. https: / / doi.org/10.1111/j.1467-954X.2000. tb03518.x

Kofta, M., Soral, W., \& Bilewicz, M. (2020). What breeds conspiracy antisemitism? The role of political uncontrollability and uncertainty in the belief in Jewish conspiracy. Journal of Personality and Social Psychology, 118(5), 900-918. https: / / doi.org/10.1037/pspa0000183

Lamberty, P., \& Imhoff, R. (2018). Powerful pharma and Its marginalized alternatives? Effects of individual differences in conspiracy mentality on attitudes toward medical approaches. Social Psychology, 49(5), 255-270. https: / / doi.org/10.1027/1864-9335/a000347

Lantian, A., Muller, D., Nurra, C., \& Douglas, K. M. (2017). "I know things they don't know!" The role of need for uniqueness in belief in conspiracy theories. Social Psychology, 48(3), 160-173. https:/ / doi.org/10.1027/1864-9335/ a000306

Lewandowsky, S., Cook, J., Oberauer, K., Brophy, S., Lloyd, E. A., \& Marriott, M. (2015). Recurrent fury: Conspiratorial discourse in the blogosphere triggered by research on the role of conspiracist ideation in climate denial. Journal of Social and Political Psychology, 3(1), 142-178. https://doi.org/10.5964/jspp.v3i1.443

Lewandowsky, S., Ecker, U. K. H., Seifert, C. M., Schwarz, N., \& Cook, J. (2012). Misinformation and its correction: Continued influence and successful debiasing. Psychological Science in the Public Interest, 13(3), 106-131. https: / / doi.org/ $10.1177 / 1529100612451018$

Lewandowsky, S., Gignac, G. E., \& Oberauer, K. (2013). The role of conspiracist ideation and worldviews in predicting rejection of science. PLOS ONE, 8(10), Article e75637. https:// doi.org/10.1371/journal.pone.0075637

Maertens, R., Roozenbeek, J., Basol, M., \& van der Linden, S. (2020). Long-term effectiveness of inoculation against misinformation: Three longitudinal experiments. Journal of Experimental Psychology: Applied. https://doi.org/10.1037/ xap0000315

Mari, S., Volpato, C., Papastamou, S., Chryssochoou, X., Prodromitis, G., \& Pavlopoulos, V. (2017). How political orientation and vulnerability shape representations of the economic crisis in Greece and Italy. International Review of
Social Psychology, 30(1), 52-67. http:/ / doi.org/10.5334/ irsp. 95

Miller, S. (2002). Conspiracy theories: Public arguments as coded social critiques: A rhetorical analysis of the TWA Flight 800 conspiracy theories. Argumentation and Advocacy, 39(1), 40-56. https: / / doi.org/10.1080/00028533.2002. 11821576

Moore, A. (2016). Conspiracy and conspiracy theories in democratic politics. Critical Review, 28(1), 1-23. https: / / doi.org/10.1080/08913811.2016.1178894

Nisbet, M. C. (2009). Communicating climate change: Why frames matter for public engagement. Environment, 51(2), 12-23. https: / / doi.org/10.3200/ENVT.51.2.12-23

Oliver, J. E., \& Wood, T. J. (2014). Medical conspiracy theories and health behaviors in the United States. JAMA Internal Medicine, 174(5), 817-818. http:/ / doi.org/10.1001/ jamainternmed.2014.190

Radnitz, S., \& Underwood, P. (2017). Is belief in conspiracy theories pathological? A survey experiment on the cognitive roots of extreme suspicion. British Journal of Political Science, 47(1), 113-129. https:/ / doi.org/10.1017/ S0007123414000556

Romer, D., \& Jamieson, K. H. (2020). Conspiracy theories as barriers to controlling the spread of COVID-19 in the US. Social Science E Medicine, 263, Article 113356. https: / / doi.org/10.1016/j.socscimed.2020.113356

Rottweiler, B., \& Gill, P (2020). Conspiracy beliefs and violent extremist intentions: The contingent effects of self-efficacy, self-control and law-related morality. Terrorism and Political Violence. https:/ / doi.org/10.1080/ 09546553.2020.1803288

Rutjens, B. T., Heine, S. J., Sutton, R. M., \& van Harreveld, F. (2018). Attitudes towards science. Advances in Experimental Social Psychology, 57, 125-165. https://doi.org/10.1016/ bs.aesp.2017.08.001

Swami, V. (2012). Social psychological origins of conspiracy theories: The case of the Jewish conspiracy theory in Malaysia. Frontiers in Psychology, 3. https: / / doi.org/ 10.3389/fpsyg.2012.00280

Swami, V., \& Coles, R. (2010). The truth is out there: Belief in conspiracy theories. The Psychologist, 23(7), 560-563.

Thorburn, S., \& Bogart, L. M. (2005). Conspiracy beliefs about birth control: Barriers to pregnancy prevention among African Americans of reproductive age. Health Education $\mathcal{E}$ Behavior, 32(4), 474-487. https: / doi.org/10.1177/ 1090198105276220

Thorburn Bird, S., \& Bogart, L. M. (2003). Birth control conspiracy beliefs, perceived discrimination, and contraception among African Americans: An exploratory study. Journal of Health Psychology, 8(2), 263-276. https: / / doi.org/10.1177/1359105303008002669

Uscinski, J. E., Douglas, K. M., \& Lewandowsky, S. (2017). Climate change conspiracy theories. Climate Science. https:/ / doi.org/10.1093/acrefore/9780190228620.013.328

Uscinski, J. E., Klofstad, C., \& Atkinson, M. D. (2016). What drives conspiratorial beliefs? The role of informational cues and predispositions. Political Research Quarterly, 69(1), 57-71. https: / / doi.org/10.1177/1065912915621621 
Uscinski, J. E., \& Parent, J. M. (2014). American Conspiracy Theories. Oxford University Press. http:/ / doi.org/10.1093/ acprof:oso/9780199351800.001.0001

van der Linden, S. (2015). The conspiracy-effect: Exposure to conspiracy theories (about global warming) decreases prosocial behavior and science acceptance. Personality and Individual Differences, 87, 171-173. https:/ / doi.org/10.1016/ j.paid.2015.07.045

van Prooijen, J.-W., \& Jostmann, N. B. (2013). Belief in conspiracy theories: The influence of uncertainty and perceived morality. European Journal of Social Psychology, 43 (1), 109-115. https: / / doi.org/10.1002/ejsp.1922 van Prooijen, J.-W., \& de Vries, R. E. (2016). Organizational conspiracy beliefs: Implications for leadership styles and employee outcomes. Journal of Business and Psychology, 31(4), 479-491. https: / / doi.org/10.1007/s10869-015-9428-3 van Prooijen, J.-W., \& Douglas, K. M. (2017). Conspiracy theories as a part of history: The role of societal crisis situations. Memory Studies, 10(3), 323-333. https:/ / doi.org/ $10.1177 / 1750698017701615$

van Prooijen, J.-W., Douglas, K., \& De Inocencio, C. (2018). Connecting the dots: Illusory pattern perception predicts belief in conspiracies and the supernatural. European Journal of Social Psychology, 48(3), 320-335. https:/ / doi.org/10.1002/ejsp.2331 